\title{
Contemporary prophetic preaching theory in the United States of America and South Africa: A comparative study through the lens of shared Reformation roots
}

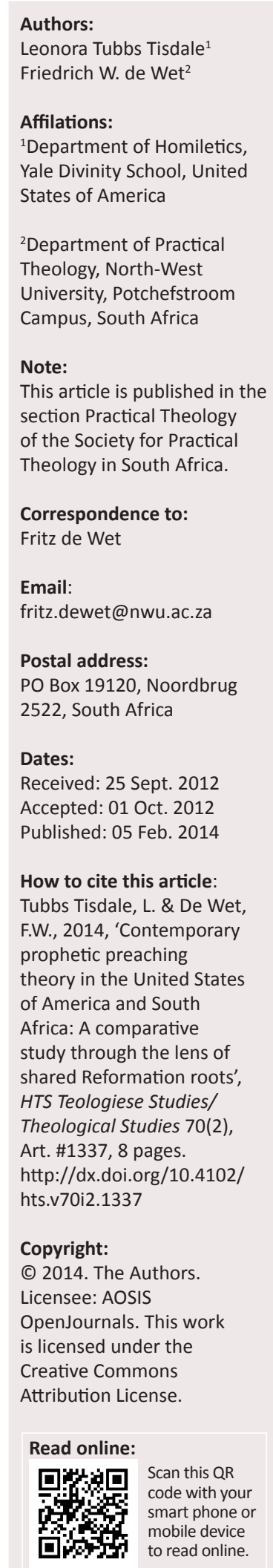

In this article two homileticians - one from the United States of America (USA) and one from South Africa (SA) - enter into a dialog regarding how the task of prophetic preaching today might be revived, reframed and redefined in light of the Reformation principle of the viva vox Evangelii [living voice of the gospel]. Each author begins by summarising four contemporary approaches to prophetic preaching set forth by Reformed and Lutheran homiletical scholars in their respective contexts. Then each addresses the questions: Where do I particularly see Reformation themes and emphases at work in the work of these homileticians? And how might those Reformation emphases continue to challenge and reframe preaching practices today? Finally, each gives initial reflections on how a comparison between the perspectives deepens and expands his or her understanding of prophetic preaching and its role in church and society.

\section{Introduction}

We write this article from two very different global contexts - South African and North American - that share a common need for a renewal of preaching that reflects the viva vox evangelii [the living voice of the Gospel] of our Reformation theological heritage. Whilst there is much preaching in our countries, there is not always sufficient emphasis upon preaching that is both rooted in God's Word revealed to us in and through the Scriptures and preaching that also attends to how that Word can become a living entity in the contemporary socio-political contexts in which we find ourselves. In short, we need a renewed emphasis upon 'prophetic' preaching - preaching that both counters and judges the status quo world views that can all too easily lead to a domestication or spiritualisation of the gospel, whilst also holding out before us a new vision of what God wills for our world. ${ }^{1}$

Marvin McMickle (2006), writing from an African-American church context in the Unites States of America (USA), asks 'Where have all the prophets gone?' Sadly, he says, prophetic witness has often been co-opted by other false gospels and emphases such as the gospel of prosperity and wealth, a focus upon individual and family 'moral values' that has not reflected the fullness of the biblical call to social justice and the rise of 'patriot pastors', who bless the nation in the name of God rather than offer a prophetic critique of its practices. McMickle (2006:119-142) calls for a faithful remnant who will boldly address the prophetic issues of our day in the name of God to rise up.

On the South African front, Reformed theologian Allan Boesak (2005) says that what is needed in his country is a renewed 'spirituality of politics':

What we are facing is not just a crisis of identity, it is a 'God crisis' ... Our social and political frigidity towards the disadvantaged, the poor and the humiliated is an expression of our frigidity toward God. (p. 221)

Boesak (2005:235) calls for prophetic witness that can reignite and foster such a 'tender-hearted and tough-minded' spirituality.

In this article, we are on a quest for how we might revive, reframe and redefine the task of prophetic preaching today in light of the viva vox evangelii of our Reformation heritage. In order to accomplish this task, we shall first summarise some of the contemporary approaches to prophetic preaching that are being set forth by Reformed and Lutheran scholars in each of our respective contexts. Next we shall address the questions: Where do we particularly see Reformation themes and emphases at work in their writings and how might those emphases continue to challenge and reframe our preaching practices today? We shall attempt this by contemplating the questions through the lenses

1.See Tisdale (2010:3-10), for a fuller definition and discussion of the nature of prophetic preaching. She identifies seven hallmarks of prophetic preaching: (1) it is rooted in the biblical witness; (2) it is countercultural; (3) it focuses more on corporate, public evil than on individual evil; (4) it names both what is not of God in the world, as well as the new reality God will bring into being; (5) it offers hope; (6) it incites courage and action in its hearers; and (7) it requires imagination, courage and conviction on the part of the preacher (p. 10). 
of our shared Reformation roots. Finally, we shall conclude with some initial reflections on how a comparison between the perspectives from our different contexts deepens and expands our understanding of prophetic preaching and its role in church and society.

\section{Prophetic preaching and reformation roots - A USA perspective ${ }^{2}$ Current visions for prophetic preaching in a USA context}

Foregrounding the prophetic nature of the biblical witness: Walter Brueggemann and Brian Blount

In the USA context, Reformed biblical scholars who write with an eye toward preaching have been amongst the foremost voices calling the church back to its prophetic witness. Walter Brueggemann's prolific work has consistently challenged pastors to reclaim the prophetic witness that lies at the very heart of the Hebrew Scriptures. For Brueggemann (2001:3), prophetic preaching is inherently counter-cultural. Its essential task is 'to nurture, nourish, and evoke a consciousness and perception alternative to the consciousness and perception of the dominant culture around us' (italics original). Prophetic witness is not about predicting the future (as some conservative theologies contend); nor is it solely about goading people into action on social issues (as some liberal theologies suggest). It is, rather a sustained effort 'to imagine the word as though YHWH were a real character and the defining agent in the life of the world ...' (Brueggemann 2012:132)

According to Brueggemann (2001:39-57), the Hebrew prophets engaged in two types of prophetic speech: the language of grief and lament, in which prophets criticised the old order and pronounced God's judgement upon its death-dealing ways, and the language of hope and amazement, in which the prophets energised their hearers by providing a new alternative vision of God's purposes for church and culture (2001:59-79). Both languages are essential to the prophetic calling, and if we only preach one of them, we do injustice to the fullness of prophetic witness.

On the New Testament front, Brian Blount (1998), who reads the Scripture through the lens of African-American cultural experience, calls upon Christians to reclaim the boundary-breaking, world-upending Jesus in Mark's gospel who proclaims the in-breaking of God's radical reign in his own preaching. Blount reminds us of our tendency in the church to domesticate the Jesus of the Scriptures and to fail to recognise that, in Mark's gospel, it was Jesus' own offensive counter-cultural ministry that ultimately led to his suffering and death at the hands of those He had angered - not some foreordained will of God (1998:131-134). Blount's own preaching - as evidenced in sermons in the book he co-authored with Gary Charles, Preaching Mark in Two Voices - places him solidly in the tradition of other outstanding prophetic African-American preachers who have not hesitated to bring the biblical witness to bear upon the pressing social issues of our day.

2.This section was written by Leonora Tubbs Tisdale from the USA.

\section{Lampooning the principalities and powers: Charles Campbell}

Charles Campbell (2000:76) of Duke University reminds us that, in prophetic preaching, we are often going up against the principalities and powers of this world and that one effective way to expose them is through burlesque or lampooning. Campbell (2002:28-88) sees preaching itself to be a nonviolent act of social protest and calls us to embrace its 'foolishness' boldly, trusting that God still uses preaching to confound the wisdom of this world. In their most recent book, Preaching Fools, Campbell and Johan Cilliers argue that Jesus used this methodology in his own prophetic witness. For example, when Jesus rode into Jerusalem on a donkey (an ancient symbol for the fool), dressed in street clothes (not a military uniform) and without any of the usual accoutrements of power, he was engaging in a protest against the pretensions of Roman rule in a way that both destabilised the claims of that rule and also proclaimed the new reign of God (Campbell \& Cilliers 2012:25-26): '[Jesus] is no passive victim,' in this story, they assert, 'but one who resists the powers that be by parodying their modus operandi - domination and violence.' Campbell and Cilliers (2012) call upon preachers today to become 'fools for Christ's sake' taking on the mantle worn by Jesus and by other prophetic witnesses (such as Archbishop Desmond Tutu) who have effectively engaged in parody in Jesus' name.

\section{Grace as the antidote to fear: Barbara K. Lundblad}

In her book Transforming the Stone, Barbara Lundblad, Lutheran professor of homiletics at Union Theological Seminary in New York, turns our attention toward the hearers of prophetic sermons and reminds us that what often lies at the heart of their resistance to prophetic preaching is fear. Because people are fearful, they strive to secure themselves against the shifting sands that surround them:

- Shore up the borders! Build a barrier to keep out immigrants (at least, those we do not want).

- Shore up the streets! Remove the homeless from our neighborhoods. Make us safer by legalising the death penalty.

- Shore up the family! Pass the 'Defense of Marriage Act' to protect traditional values.

- Shore up the church! Return to tradition. Silence the voice of feminists. Get back to the Bible. (Lundblad 2001:15)

Ignoring the fears does not make them go away, Lundblad asserts (2001:18). We as preachers must name and address them. Yet ultimately the most effective antidote to fear is a strong emphasis in our preaching on grace, as Lundblad (2001) asserts:

It is the assurance of grace that provides the ground for transformation. From this grounding the preacher can move on to call for repentance, to urge new behavior or to empower people to risk radical social change - but the starting point is the good news that God's grace has come near. (p. 29)

Lundblad offers a number of effective strategies in which preachers can engage in order to 'preach through resistance to change.' But at the heart of them all is a grace that alone has the power to transform hearts and lives. 


\section{Preaching prophetically in a pastoral way: Leonora Tubbs Tisdale}

In my own book Prophetic preaching: A pastoral approach, I address the tensions contemporary pastors encounter between their dual roles as prophets and priests, encouragers and gadflies. Unlike many of the Hebrew prophets of old, contemporary pastors do not have the privilege of drawing a distinction between these two roles of ministry and consequently can find themselves avoiding prophetic preaching - sometimes for pastoral reasons (cf. Tisdale 2010:10-20). At its heart, this book is an attempt to address the question: How can we preach prophetically in a more pastoral way? The goal is not to water down the two-edged gospel so that it becomes more palatable to our congregations. Rather the aim is to examine the strategies and forms we use in prophetic preaching in order that we as preachers might (1) remove any 'wrong stumbling blocks' (a phrase theologian Paul Tillich uses [cf. Tillich 1959:213; Tisdale 2010:41-42]) we as preachers are putting in the way of our congregations' hearing and responding to God's prophetic Word, and (2) adopt alternative strategies and forms that can help us communicate that prophetic Word more effectively (cf. Tisdale 2010:41-88 for a detailed discussion of strategies and forms that can be effective in prophetic witness). Ultimately I argue that we do not need to draw a strong divide between preaching that is 'pastoral' and preaching that is 'prophetic.' Prophetic preaching can be an extension of our pastoral care for our flocks (as we address all the societal issues and concerns that confront people in their daily lives), whilst adopting a more pastoral approach to prophetic witness can open the way for greater congregational response and engagement. The aim of such preaching is always to build up the body of Christ so that our faith communities might themselves preach - in word and indeed - the whole cuttingedge gospel of God.

\section{Reformation roots of prophetic preaching - USA perspectives}

There are a number of significant Reformation themes that are evidenced in the works of the authors cited above, many of which are deserving of a renewed emphasis in contemporary USA church culture. Certainly one such theme is the primacy of grace that comes through in Barbara Lundblad's work. When prophetic preaching is not grounded in grace, it often ends up sounding like works righteousness ('if you truly want to be saved, then you must engage in these particular acts of social justice') or like a harangue in which the preacher takes the congregation to task for its recalcitrance and inaction. But Luther's reminder (via the apostle Paul) that all of us are saved solely 'by grace ... through faith' (Eph 2:9) takes us back to the heart of Reformation faith and, in the process, places pastor and people standing together under the God who judges and redeems us all in Christ.

A second theme, reflected in the work of Walter Brueggemann, relates to John Calvin's emphasis on reading and preaching the whole of Scriptures in worship, and not just a portion thereof. Calvin is known both for advocating for a lectio continua reading of Scripture in worship (that is, reading and preaching through entire books of the Bible as opposed to only preaching selected pericopes in a lectio selecta manner) and also for giving greater attention to the reading, hearing and preaching of Old Testament Scripture as well as New Testament Scripture in worship (witness his reclamation of psalm-singing in worship, as well as the way in which he preached through entire books of the Old Testament during his ministry in Geneva). Whilst there have been many wonderful benefits that have come from the adoption of 'lectionary-based' preaching', this trend has also had some detrimental effects. A first is that lectio continua preaching is increasingly rare amongst the 'mainline' churches, so that congregations do not have the experience of spending an entire month or season hearing sermons based on one of the prophetic books of the Bible. A second trend is that whilst Old Testament lectionary texts are often read aloud in worship, they are far less regularly preached than New Testament (and especially Gospel) texts. Whilst this tendency is less common amongst some African-American congregations (where a strong identification with the liberation story of the Hebrew people has, in part, led to a love for the Old Testament and its preaching), it is heightened in more highly liturgical church traditions (Episcopal, Lutheran, Roman Catholic) where the service frequently leads to a celebration of the Eucharist, and the sermon, consequently, tends to have a more Christological (and New Testament) focus. Whilst preachers in evangelical and Pentecostal traditions have had the freedom to preach on biblical texts of their choice, many gravitate either toward topical preaching (with sermon series structured around particular themes) or toward the selection of texts which are deemed to be more 'spiritual' and less 'prophetic' in nature. Consequently, Calvin's call for a renewed focus on preaching the whole of scripture and Brueggemann's call to the church to reclaim the Hebrew prophets in particular are timely appeals for USA congregations.

A third theological theme that emerges amongst these authors is a Reformed emphasis on avoiding idolatry in the life of faith (cf. Calvin 1977:I:XI, XII). Calvin tells us that the Scriptures are to be the 'spectacles' through which we view the world and discern more clearly what is of God and what is not of God there (1977:I:VI.1), but postmodernism reminds us that we view Scripture itself through cultural 'spectacles' that can make us highly myopic and biased in the ways we read and interpret texts. Certainly if we in the USA look at the history of biblical interpretation around racial issues, women's issues and issues related to homosexuality, we can readily see how that which we have proclaimed as 'truth' in one generation has been confessed to be 'sinful' and 'idolatrous' by the next. We need the priesthood of all believers - and especially the vision of marginal and oppressed members of our faith communities - to help correct our myopic and idolatrous

3.Many Protestant denominations in the USA either require or strongly encourage their ministers to preach from the 'Revised Common Lectionary', a three-year cycle their ministers to preach from the 'Revised Common Lectionary', a three-year cycle
of biblical texts that follow the liturgical year and are prescribed for use in Sunday morning worship. 
tendencies. ${ }^{4}$ We also need those members of the global faith community who help us recognise the ways in which we have domesticated Jesus or recreated him in our own cultural image, rather than allowing his radicality to confront and convict us. This is where the work of Brian Blount, Charles Campbell, Johan Cilliers and a host of womanist, feminist, two-thirds world and liberation scholars become critical for us.

Finally, many of these authors remind us that, in Reformation understanding, preaching has as its goal the forming and reforming of ecclesial identity in the world. We preach prophetically not only so that we as preachers might be more faithful to God and to the witness of Scripture but also so that the 'priesthood of all believers' might be empowered to preach prophetically in word and deed in the world. I conclude Prophetic Preaching with a chapter entitled 'Word and deed: The integrity of prophetic witness.' In it, I write:

If we truly believe that it is the church that is called to give prophetic witness and not just the pastor, then sermons on prophetic issues will necessarily call on the entire Christian community to become involved in actions on behalf of God's justice in the world. (Tisdale 2010:98)

Barbara Lundblad (2001:13) echoes this theme when she calls for the 'transformation' through preaching of local faith communities and reminds us that such transformation is always a gift of God.

\section{Prophetic preaching and reformation roots - a South African perspective \\ Current visions for prophetic preaching in a South African context}

\section{Clowning for change: Johan Cilliers}

When Stellenbosch-based professor in homiletics and liturgics, Johan Cilliers (2009:190-192), considers some of the great exponents of Reformed theology (Calvin, Schleiermacher, Barth, etc.), he finds that the concept of comic vision is not something foreign to this tradition. As a matter of fact, it is an image that links meaningfully to certain theological topics within this tradition, such as the role of the church as alien and temporary sojourner in this world (cf. 1 Pt 2:11). Like a clown, the church does not fit in. Its position 'between the times' remains rather precarious and, for some, hilarious. For preachers, this means we should play the fool and by so doing frustrate these powers. We should juxtapose and thereby jolt the systems. We should subvert and thus shatter the status quo. The tool for doing this is not the sword (violence) but the word (and ultimately, the Word). Cilliers (2009:194) visualises the following role for the word/ Word in preaching: The language of denial or stabilisation needs to be disrupted by the gospel's rhetoric of vulnerable madness. The preacher stutters the 'unspeakable meaning' of the vulnerable Word in the holy, nonsensical endeavour

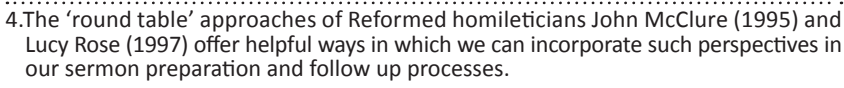

5.This section was written by Friedrich W. de Wet from SA. of preaching, unsettling normative discourse and unmasking and lampooning the pretenders to power.

\section{A theodramatic paradigm for prophetic preaching: Ian Nell}

Utilising elements like Hans Urs Von Balthasar's (1983) concept of Theo-drama and Kevin Vanhoozer's (2005) canonicallinguistic approach to Christian Theology, Stellenbosch-based practical theologian, Ian Nell (2009:571-576, cf. 2011:107), develops a theodramatic paradigm for prophetic preaching: Doctrine serves the church, the theatre of the gospel, by directing individuals and congregations to participate in the drama of God's action to renew all things in the Lord Jesus Christ. Nell further contends that, whilst the Holy Spirit is the primary director who oversees the global production, it is the pastor who bears the primary responsibility for overseeing local performances. The pastor is an assistant director at best, aided in turn by the theologian as dramaturge. Following the cue of Vanhoozer, the first commandment of the director is seen as obedience to the text. Therefore the analysis of the play is of major importance in directing the process of preaching. In addition, the director has to communicate the interpretation of the script to the actors and audience, train the actors and get them to work together. In this interaction between the pastor and the other congregational role-players, the local theatre of congregational theology turns into a prophetic community by communicating the meaning of the play through its bodily action. By acting as apprentice to creedal theology, the prophetic preacher in conversation with the congregants helps the local church to understand its role in the light of the universal church. Thus one also realises that the local church is not the first company attempting to stage performances from Scripture content. By using the Belhar Confession's $\mathrm{s}^{6}$ underlying theological framework as a guide, Nell singles out 'three acts of the plot' when one accepts the challenge of performing prophetic preaching within a South African context. He calls these three acts 'taking hands' (unity), 'embracing each other' (reconciliation) and 'giving back the bicycle' (justice).

\section{A hermeneutical approach in the context of poverty: Hennie Pieterse}

Prolific South African researcher in the field of homiletics, Hennie Pieterse, regards preaching in its very essence to be situational and topical. According to Pieterse, it is impossible to ignore the poor in SA context and merely preach about faith as a private, spiritual matter. Prophetic preaching is contextual. Its approach is from the angle of the poor and their need for justice and righteousness (Pieterse 2012:7). Referring to insights of liberation theology as documented in works by Leonardo Boff (1989) and John De Gruchy and Charles Villa-Vicencio (1994), the Bible is specifically

6.The Belhar Confession can be traced to a Christian statement of belief originally written in Afrikaans in 1982, focusing on unity as gift and obligation for the church and stressing that all forms of segregation lead to enmity and hatred. This document was stressing that all forms of segregation lead to enmity and hatred. This document was adopted as a confession of faith by the synod of the Dutch Reformed Mission Church in South Africa in 1986. In 1994 the Dutch Reformed Mission Church and the Dutch Reformed Church in Africa united to form the Uniting Reformed Church in Southern Africa (URCSA). As a prerequisite to join this united denomination it was asked of the previously whites-only Dutch Reformed Church in South Africa (DRCSA) that all of its members should adopt the Belhar Confession (Med Library.org n.d.). 
read with a 'preferential option for the poor' (Pieterse 2001:82). Translation (trans-lation) for the purpose of a prophetic sermon is, however, also an interpretation of the text in such a way that its intention is not lost. Imaginative, relevant translation of a text for a sermon means inquiring hermeneutically into the intention of the text and then, by means of a confrontational dialogue between the reader and the text, allowing it to progress dynamically to a new, liberating message in the present-day context. The scripturally fixed words of the text become a Word event all over again, a speech act, with new, relevant meaning for the listeners' situation (Pieterse 2012:7, 8).

\section{A voice against oppression proceeding from an activist interpretation of the Calvinist tradition: Allan Boesak}

Utilising themes from liberation theology, like those developed by James Cone and Gustavo Gutierrez, the well-known antiApartheid activist, Allan Boesak, calls the church to break its silence and to speak out against oppression. The intentional decision of the oppressed to break free from the slave mentality enforced on them by a system like Apartheid is, according to Boesak (1977:10), a key theme in the philosophy of black Consciousness. All South Africans should disengage from a 'pseudo-innocence' that distorts our reality and closes our eyes to matters we find too horrendous to contemplate, causing us to make a virtue of powerlessness, weakness and helplessness. The moment people begin to realise that their position is not a matter of a predestined and unchangeable fate, a vision is born for actively taking responsibility in the outcome of their lives (Boesak 1977:10, cf. 2009:3). In his postapartheid contributions, Boesak continues to call the church to resist all new forms of idolatry, as they are manifest in Western European and Euro-American imperialist thinking. According to Boesak, we need a process of 'decolonisation' which will help us undo the domestication of Jesus, Paul and the writings of the New Testament (Boesak 2009:6).

It is important to note that Boesak's (1986) call to speak out against oppression is deeply rooted in an activist interpretation of the Calvinist tradition. Contra the ruling notion during the apartheid years that being reformed had to do with uncritical acceptance of the status quo and manipulation of the word of God in order to justify oppression (1986:93), Boesak maintained that he could be black and reformed at the same time. Boesak (2010) writes:

My call for massive civil disobedience to the South African Council of Churches and for direct involvement of the churches in the struggle for liberation in 1979 was informed by the radical Calvinism I had come to know and embrace. (p. 295)

The call for tough-minded disobedience - in Boesak's case - proceeds from an activist 'spirituality of politics' that goes hand in hand with the Calvinist concept of 'tenderness of conscience'. Tenderness of conscience, according to Boesak (2010:300), brings us the gift of human solidarity, the solidarity of hopeful resistance to our sinful carelessness and tendencies of self-possessed selfishness which South Africa, in our efforts against our fragmented past and for our common future as a nation, cannot do without.

\section{Reformation roots of prophetic preaching: South African perspectives}

All four portraits (briefly pictured in the previous section) work with the status quo-shattering power of the living Word of God but from different angles. The odd presence of the Word in the world, the dramatic enactment and embodiment of the Word, the Word in living hermeneutical contact with the actual preaching context and the Word in its passion for the oppressed form a rich tapestry for coming to grips with the task of prophetic preaching in the current SA landscape. The question is: What contribution can a re-visitation of the Reformation roots (that underlie all four portraits) in ecumenical dialogue with a similar re-visitation made in USA context make in challenging, deepening and refining the vision for prophetic preaching and the challenges posed to it in contemporary context?

In the opinion of Johan Cilliers, the Reformation was all about the dynamic interaction between reframing (seeing new) and being reformed (becoming new). The Reformation was a pastoral movement of reform, as much as it was an act of reframing (Cilliers 2010a:87). Cilliers reasons that the frame through and within which we observe reality reveals and forms our images of God and humanity (2010a:88). Preaching is all about this framing and reframing of our perspectives ultimately about being reframed by the actions of God that open up dimensions far beyond what we could imagine.

Where the Renaissance emphasised faith in the rationality and creativity of the human person, the Reformation focused on faith in the Word of God (Van der Walt 2010:39; cf. Fowler 2008:20). Re-visiting the Reformed roots (even for a seeker coming from a Reformed-Calvinistic tradition) cannot be done without retracing the steps to the Copernican figure of Martin Luther and his bold faith in the Word of God and its living power.

Historical theologian, Mark D. Thompson, reasons that Luther's assertions about the origin, nature and use of Holy Scripture are profoundly connected to other major themes in his theology. His views on the nature of Scripture are closely connected to his teaching on the incarnation of the Word and the theology of the cross (Thompson 2004:284). In returning to Scripture and the Early Fathers, as renowned historiographer of the Reformation, Lewis W. Spitz, points out, Luther did not merely restore the original ideas of Paul and Augustine but aligned himself creatively with them. His was a theology of the Word, the Christ of the Scriptures. By placing his 'theology of the cross and suffering' against the traditional 'theology of glory', which he claimed could encourage a false spiritual pride (Spitz 2001:85), Luther's boldness in speaking on the origin, nature and use of the Word of God clearly does not flow from confidence in the merit of his own nature. In a letter to Lazarus Spengler (LW 49:356-59), Luther explains his theological vision with the symbol of rose petals arranged around its heart (see Figure 1), marked by the cross of Christ. 


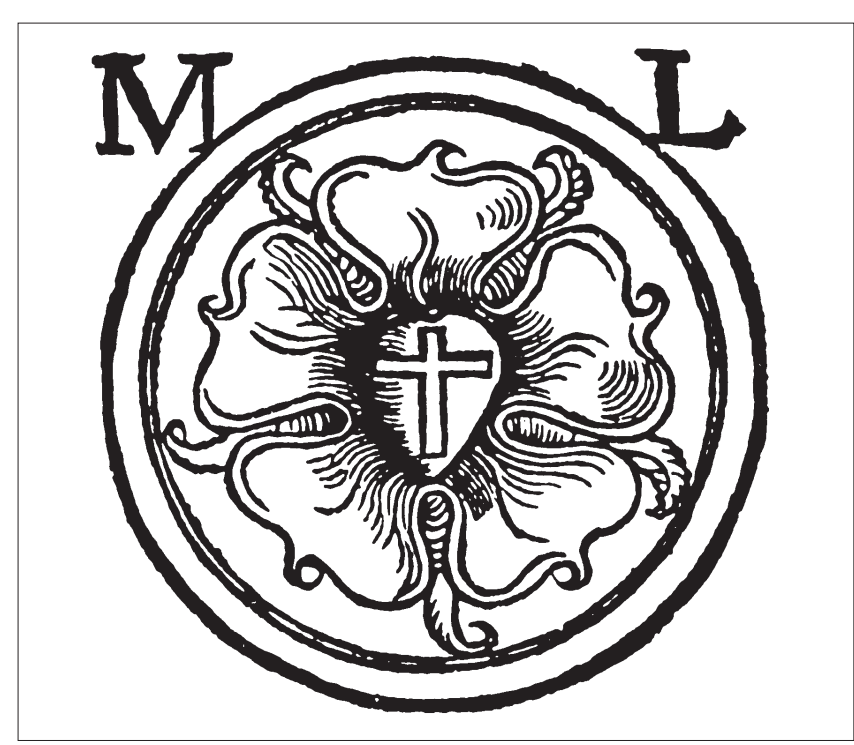

Note: For a detailed discussion regarding this particular seal and its theological significance see Korsch, D., 2000, 'Luther's seal as an elementary interpretation of his theology', transl. A. Marga, Lutheran Quarterly 14(4), 409-431.

FIGURE 1: A seal representing Martin Luther's theological vision as probably adapted from his family's coat of arms.

There is first a cross, placed in the heart, which should remind us that only faith in the Crucified saves us. Such a heart is to be set in the midst of a joyous rose, symbolising the comfort and peace faith gives. The just person does not live in his or her own power but only by faith in the Crucified One.

In Luther's theology (as is the case in Protestant theology in general), the Word of God is understood kerygmatically. According to Luther, Christ wrote nothing and spoke everything. The Apostles wrote little and spoke much. The office of the new covenant is not built on tables of stone that are dead but on the sound of the living voice (WA 5:537). These words of Luther clearly gave momentum to one of the catch phrases in Protestant theology: viva vox evangelii [the living voice of the Gospel]. God's Word is first and foremost the preached Word. The Word of God is not simply identical with the Bible. As Lutheran theologian Klaus Nürnberger reminds us, it is the living address of the living God to living people through the words, the fellowship and the behaviour of a living community of believers (Nürnberger 2006:4; cf. Asendorf 2000:229).

In the field of tension between the ambiguous experience of God's power in everyday life (where Deus absconditus is at work) and the experience of God's grace in the creative, redemptive and transformative impact of the Word of Deus revelatus, Nürnberger (2006) asks:

On what grounds can people muster the boldness to proclaim that God is unquestionably committed to our well-being? How do they know that God is indeed a God of justice, of righteousness and of redeeming love? (p. 24)

Luther's answer (according to Nürnberger) is that this assurance can paradoxically be gathered from the cross of Christ. God saves through destruction; he builds by tearing down; his strength comes through weakness. Through the message of the cross of Christ, spoken by a human voice in an humble form (as an embodiment of the larvae Dei [masks of God]) - because no one would survive if he should speak in his full glory as naked God (Deus nudus) - God's Word is heard, liberating the weak from their agony and opening up a new future for those without hope (cf. Cilliers 2010b:40).

What contribution can a re-visitation of the Reformed roots (specifically pertaining to Luther's vision of the viva vox evangelii) make in challenging, deepening and refining the vision for prophetic preaching and the challenges posed to it in contemporary context? To my mind, imagining the existential implications of Luther's joyous rose with its crossmarked heart as point of departure (lens) for reframing the four homiletical portraits opens up a surprising scope and depth for the prospective task of addressing the problems that have to be faced in the current South African situation. Luther's vision helps me to imagine liberating joy flowing paradoxically from the dangerous core task of prophetic preaching in facing the power structures at play in the complex, troubled heart of South African society. The complexities involved are indeed overwhelming: The Truth and Reconciliation Commission ${ }^{7}$ has concluded its mandated task, but thinking South Africans are only now beginning to recognise the unfinished business at hand. We have not yet successfully dealt with the past in achieving true reconciliation. We have not overcome racism and economic segregation, nor fully acknowledged and dealt with the human complicities involved. The power structures at play in our society (including the tolerance of a notorious and deeply rooted culture of corruption) can release eroding acids of despair and overwhelming cynicism that threaten all efforts to deal creatively with the problems at hand, as Christian humanist John De Gruchy points out (De Gruchy 2011:3). However, in the heart of this troubled land, I can envisage the presence of the cross of Christ and can develop a joyous prophetic vision - anticipating that the impossible will be made possible.

The act of reframing the four homiletical portraits - through the lens of Luther's theology enables:

1. Boldness to speak the foolish word of the cross of Christ in faith that the oppressive and manipulative power structures, which proceed from corrupt, arrogant and self-righteous human wisdom, cannot keep divine power and wisdom from paradoxically saving those in my land who find themselves in a position where their lives seem to mean and matter nothing.

2. Enactment and embodiment of the Word in a Theodrama that envisions events leading to much-needed and transformative unity, reconciliation and justice - a reality that is not attainable through our own efforts or by what is artificially created or staged but that is only possible in the creative power of the Crucified and Resurrected One.

7.The Truth and Reconciliation Commission (TRC) was a court-like restorative justice body assembled in South Africa after the abolition of Apartheid. Witnesses who were body assemb in identified as victims of gross human rights violations were invited to give statements about their experiences, and some were selected for public hearings. Perpetrators of violence could also give testimony and request amnesty from both civil and crimina prosecution. 
3. A living hermeneutic in which the Word touches our vulnerable people at the core of their existence with a liberating joy that breaks through where they least expect it (as opposed to a fruitless dialogue between a dead letter and a disillusioned people seemingly trapped forever in the vicious cycle of poverty).

4. A tough-minded and tender-hearted prophetic vision sharpened and energised by the Word who identifies with the oppressed and reveals the wisdom and power of God in and through them.

\section{Comparative remarks and conclusion}

At the end of this comparative study, we would make the following observations:

In both of our (very different) preaching contexts, Reformed and Lutheran scholars have been key voices in calling the church to a renewed prophetic vision. We are grateful for their ongoing witness in our countries and for the ways in which they prod us to embrace the fullness of God's living prophetic Word in our preaching.

Scholars in both of our contexts also give voice to many significant Reformation theological themes in their writings. The grace of God, the centrality of the cross, the call to preach the whole of the scriptures, the priesthood of all believers and the folly of preaching itself are but a few of the central tenets of Reformation faith that continue to press the church toward a fuller embrace of the viva vox evangelii.

Finally, whilst our contexts are indeed different, some of the issues prophetic preaching needs to embrace are similar like race and racial relations, unemployment, immigration reform, the ever-widening divide between the rich and the poor and the ways in which justice issues and environmental issues intersect and interrelate. We have much to learn from one another - and indeed from other prophetic preaching contexts around the globe - about how to undertake this task with wisdom, clarity and thoughtful compassion.

I (Nora) am grateful for the breadth and depth of theological grounding that South African scholars bring to their approaches to prophetic preaching. Cilliers' work reminds us that prophetic preaching participates in the very foolishness of God revealed to us in Christ and that our call as church is to become 'clowns' for the gospel as well. Nell's work calls us to see theologians as partners in the dramatic reenactment of the gospel in the life of local congregations and to allow the church's own prophetic confessions to guide our interpretations of that gospel. Pieterse adopts central tenets of liberation theology (such as God's preferential option for the poor) in his own hermeneutical approach to prophetic preaching. And Boesak, with his radical Calvinist theology, calls for liberation from all that shackles the oppressed in their witness and boldness in reclaiming preaching as the realm for spirituality and politics. For all of these scholars, theology is critical for faithful prophetic preaching, and their voices are sorely needed in the USA context where prophetic preaching can fall prey either to an overly facile application of biblical solutions to complex social problems or, alternatively, to an exegesis of prophetic texts that is devoid of deep theological and ethical reflection in light of the current context.

I (Fritz) am particularly struck by the element of boldness in prophetic witness that comes through in Tubbs Tisdale's discussion of USA approaches to prophetic preaching. This is a boldness that is born not of self-righteousness but that arises out of faith in God's grace. It does not focus upon its own narrow truth but upon the fullness of the whole of Scripture in all its organic unity. It depends upon the priesthood of all believers for its rich language and insight. And it is undertaken not in harshness (so unbearably a part of our legacy) but with the sensitivity and compassion of a pastor priest who walks amongst her people in humility and takes them with her. Such boldness in the pulpit offers courage and newfound joy to speak the living Gospel of the Crucified and Resurrected One in all its boundary-shattering fullness.

In short, we have learned much from this comparative study about how prophetic preaching in each of our contexts can be encouraged and challenged to become a deeper and fuller expression of the 'viva vox evangelii' the Reformers envisioned.

\section{Acknowledgements Competing interests}

The authors declare that they have no financial or personal relationship(s) that may have inappropriately influenced them in writing this article.

\section{Authors' contributions}

L.T.T. (Yale Divinity School) researched exponents of prophetic preaching in the USA context and theologically reflected on the Reformation roots of prophetic preaching in the USA context. F.W.d.W. (North-West University) researched exponents of prophetic preaching in the South African context and theologically reflected on the Reformation roots of prophetic preaching in the South African context. Both authors contributed co-operatively to the introduction and to the comparative study as it is reflected at the end of the article.

\section{References}

Asendorf, U., 2000, 'Viva vox evangelii: A necessary course correction', in D.O. Wenthe (ed.), All Theology is Christology: Essays in Honor of David P. Scaer, transl. K.D. Schulz, pp. 229-241, Concordia Theological Seminary Press, Ft. Wayne, IN.

Begg, R., 2007, 'American and South African socio-historical liberation theology reciprocative influences', Scriptura, 96, 316-325.

Blount, B.K., 1988, Go preach! Mark's kingdom message and the Black church today, Orbis Books, Maryknoll, NY.

Boesak, A.A., 1977, Afscheid van de onschuld-Een social-ethische studie over zwarte theologie en zwarte macht, Kok, Kampen.

Boesak, A.A., 1986, Black and reformed: Apartheid, liberation and the Calvinist tradition, Skotaville Press, Johannesburg.

Boesak, A.A., 2005, The tenderness of conscience: African renaissance and the spirituality of politics, Sun Press, Stellenbosch.

Boesak, A.A., 2009, 'Theological reflections on empire', HTS Teologiese Studies/Theological Studies 65(1), Art. \#291, 7 pages. http://dx.doi.org/10.4102/hts.v65i1.291 
Boesak, A.A., 2010, 'At the heart of it all: Perspectives on the struggle for the relevance of the Reformed tradition in South Africa', Nederduitse Gereformeerde Teologiese Tydskrif 51, 289-301. (Supplementum, Teologie 150+ en Calvyn 500).

Boff, C., 1989, Optie voor de armen, Altiora-Averbode, Appeldoorn.

Brueggemann, W., 2001, The prophetic imagination, 2nd edn., Fortress Press, Mineapolis, MN.

Brueggemann, W., 2012, The practice of prophetic imagination: Preaching an emancipating Word, Fortress Press, Minneapolis, MN.

Calvin, J., 1977, Institutes of the Christian religion I and II: The library of Christian classics, ed. J.T. McNeill, tranls. F.L. Battles, Westminster Press, Philadelphia, PA.

Campbell, C.L., 2002, The Word before the powers: An ethic of preaching, Westminster/ John Knox Press, Louisville, KY.

Campbell, C.L. \& Cilliers, J.H., 2012, Preaching fools: The gospel as a rhetoric of folly, Baylor University Press, Waco, TX.

Campbell, C.L. \& Saunders, S. P., 2000, The Word on the street: Performing the Scriptures in the urban context, William B. Eerdmans Publishing Co., Grand Rapids, MI.

Cilliers, J.H., 2009, 'Clowning on the pulpit? Contours of a comic vision on preaching', Scriptura 101, 189-197.

Cilliers, J.H., 2010a, 'Preaching as reframing of perspective', In die Skriflig/In Luce Verbi 44(1), 85-97. http://dx.doi.org/10.4102/ids.v44i1.138

Cilliers, J.H., 2010b, 'The absence of presence: Homiletical reflections on Luther's notion of the masks of God (Larvae Dei)', Acta Theologica 30(2), 36-49.

De Gruchy, J.W. \& Villa-Vincencio, C., 1994, Doing Theology in context: South African perspectives, David Philip, Cape Town.

De Gruchy, J.W., 2011, 'The humanist imperative in South Africa', South African Journal of Science 107(7/8), Art. \#804, 3 pages. http://dx.doi.org/10.4102/sajs.v107i7/8.804

Fowler, S., 2008, Living worldviews, Amani Educational Services, Melbourne.

Korsch, D., 2000, 'Luther's seal as an elementary interpretation of his theology', transl. A. Marga, Lutheran Quarterly 14(4), 409-431.

Lundblad, B.K., 2001, Transforming the stone: Preaching through resistance to change, Abingdon, Nashville, TN.

Med Library.org, n.d., Belhar Confession, viewed 29 January 2013, from http://medlibrary. org/medwiki/Belhar_Confession

McMickle, M., 2006, Where have all the prophets gone? Reclaiming prophetic preaching in America, Pilgrim Press, Cleveland, OH. PMid:17077828
McClure, J.S., 1995, The round-table pulpit: Where preaching and leadership meet, Abingdon Press, Nashville, TN.

Nell, I.A., 2009, 'In search of meaning: Moving from the prophet's voice to prophecy in community: A South African perspective', Scriptura 102, 562-578.

Nell, I.A., 2011, 'Calvyn as "praktiese teoloog": Die bydrae van ' $n$ teodramatiese paradigma', In die Skriflig/In Luce Verbi 45(1), 97-120. http://dx.doi.org/10.4102/ ids.v45i1.7

Nürnberger, K., 2006, Martin Luther's message for us today: A perspective from the South, Cluster, Pietermaritzburg. PMCid:1785393

Pieterse, H.J.C., 2001, Preaching in a context of poverty, UNISA Press, Pretoria. PMCid:64867

Pieterse, H.J.C., 2012, 'Prophetic preaching in the contemporary context of South Africa', lecture presented at the University of Pretoria, Pretoria, 13 April 2012.

Rose, L.A., 1997, Sharing the Word: Preaching in the roundtable church, Westminster John Knox Press, Louisville, KY.

Spitz, L.W., 2001, The protestant Reformation (1517-1559), Concordia, St. Louis, MO.

Thompson, M.D., 2004, A sure ground on which to stand: The relation of authority and interpretive method in Luther's approach to Scripture, Paternoster, Exeter.

Tillich, P., 1959, Theology of culture, ed. Robert C. Kimball, Oxford University Press, New York, NY.

Tisdale, L.T., 2010, Prophetic preaching: A pastoral approach, Westminster John Knox Press, Louisville, KY.

Van der Walt, B.J., 2010, 'Calvin and the spiritual trends of his time: The uniqueness of the sixteenth-century', In die Skriflig/In Luce Verbi 44(4), 23-45. http://dx.doi. org/10.4102/ids.v44i4.178

Vanhoozer, K.J., 2005, The drama of doctrine: A canonical-linguistic approach to Christian theology, Westminster John Knox Press, Louisville, KY.

Von Balthasar, H.U., 1983, Theo-drama: Theological dramatic theory: V: The last act Ignatius Press, San Francisco, CA.

Martin Luther sources

LW = Luther's Works: Pelikan, J. \& Lehmann, H.T. (eds.), 1955-1986, Luther's Works, American Edition (56 vols.), Concordia and Philadelphia: Muhlenberg and Fortress, St. Louis, MO.

WA = Weimer Ausgabe: Knaake, J.K.F. et al (eds.), 1883ff., Luthers Werke, Kritische Gesamtausgabe, Weimar. 